\title{
Adoption of Agricultural Marketing Technologies by Farmers of Northern Bangladesh: A Binary Logistic Analysis to Determine the Factors Influencing Farmers' Decision
}

\author{
Md. Ziaul Haque \\ PhD Fellow, Institute of Bangladesh Studies (IBS), Rajshahi University, Rajshahi, BANGLADESH \\ *E-mail for correspondence: ziaul.eco.78@gmail.com
}

https://doi.org/10.18034/abr.v9i3.338

\begin{abstract}
Low adoption of agricultural marketing technologies in the field of agricultural commodities marketing is one of the main reasons for profit loss of the farmers in Bangladesh. This paper examines the factors that influence farmers' decision of modern agricultural marketing technologies adoption in Northern Bangladesh. By using questionnaire survey the researcher collect data from 216 farmers in Dinajpur and Naogaon district in Northern Bangladesh and the binary logistic regression model was estimated to find out the factors influence farmers decision. Seven independent variables i.e. age of the farmer, formal education of the farmer, farm size, level of expected benefits, off-farm income generating activities, access to institutional credit and training about use of marketing technologies are statistically significant factors that influence the decision of farmers to adopt modern agricultural marketing technologies in Northern Bangladesh. So it is concluded that the farmers' decision to adopt modern agricultural marketing technologies depends on their socio-economic status and organizational effectiveness. We recommend that such policies should be made so that the positive impact factors on technologies adoption are properly utilized and negative issues are reduced.
\end{abstract}

Key words: Agricultural Marketing, Binary Logistic Regression, Marketing Technologies, Farmers' Decision

\section{INTRODUCTION}

Agriculture in Bangladesh has directly or indirectly continued to be the source of livelihood to the majority of the population. Agriculture is the single largest sector of the economy and contributes $16.96 \%$ to the total Gross Domestic Product (GDP) of the country (BBS, 2015). This sector also accommodates around $47.51 \%$ of labor force (BBS, 2015). GDP growth rate of Bangladesh mainly depends on the performance of the agriculture sector.

From the very early stages of development of the human society, exchange has become an indispensable part of human civilization. Even before the introduction of the money economy, there prevailed what economists termed as "barter system" based on direct exchange of goods for goods. With the introduction of money as the medium of exchange, there came a change in the farming pattern from the self-sufficient village economy to the market economy of production for the market. The agricultural commodity marketing system provides the bridging link between farm produces and the consumers of food and agricultural products. As agricultural products need to be marketed, there is a need for building a strong market infrastructure to bring efficiency in marketing services. Development of efficient agricultural marketing system will, therefore, help farmers enhance their bargaining power and enable them to fetch better prices for their produces (Bangladesh Agricultural Policy, 2009).

With the use of advanced production technology in the agriculture of Bangladesh, the production of every commodity has increased surprisingly. But in the field of marketing of agricultural commodities, farmers of this country adopt ancient methods. As a result, the inefficiency of marketing of agricultural commodities remains inaccessible and the farmers lose profit. Fully utilized of the possibility of marketing of agricultural produce in the country is depends on the innovativeness of performers in the agricultural sector, predominantly farmers. The ability of farmers and other actors along the agricultural value chain to modernize in their marketing activities is depending on the accessibility of technology. 
The accessibility of modern agricultural marketing technologies to marginal users, and the capacities of marginal users to adopt and use these technologies are critical. Unfortunately, the agriculture of Bangladesh is characterized by low level of marketing technology adoption and for this region, the farmers of Bangladesh have to be satisfied with the low profit. The government of Bangladesh have implemented various steps to promote marketing technology adoption between farmers. So, unraveling the reasons for low adoption of marketing technology among farmers requires that the factors that influence their decision to adopt or not to adopt modern agricultural marketing technologies be identified.

This paper, therefore, examines the different factors that influence the adoption of modern agricultural marketing technologies among farmers in Northern Bangladesh.

\section{LITERATURE REVIEW}

Different factors determine the adoption of agricultural inventions and technologies. Some literature focuses on farm size as the first and maybe the most important factor that affects technological adoption. Daku (2002); Doss and Morris (2001); Boahene et al. (1999); Fernandez-Cornejo (1998); Nkonya et al. (1997); Green and Ng'ong'ola (1993) and Harper et al. (1990) found that farm size influence farmers' decision to adopt modern technology. This is because farm size can affect and in turn be affected by the other factors influencing technological adoption. The effect of farm size on technological adoption could be positive, negative or neutral. For example, Kasenge (1998); Fernandez-Cornejo (1996); Abara and Singh (1993); McNamara et al. (1991) and Feder et al. (1985) found farm size to be positively related to adoption. On the other hand, Yaron et al. (1992); and Harper et al. (1990) found negative relationship among adoption and farm size. Amusingly, Mugisa-Mutetikka et al. (2000) found that the relationship between farm size and adoption is unbiased. It has been argued that large fixed costs become a constraint to technology adoption for small farms (Abara and Singh, 1993), particularly if the technology requires a significant amount of initial arrangement cost. In this regard, Feder et al., (1985) mention that only larger farms will adopt these kinds of inventions. For some technologies, the swiftness of adoption is different for small and large scale farmers.

Age is an important factor that influences the probability of adoption of modern technologies because it is said to be a primary latent characteristic in adoption decisions. However, there is debate on the trend of the effect of age on technological adoption. Age was found to positively affect adoption of sorghum in Burkina Faso (Adesiina and Baidu-Forson, 1995) and control of rice stink bug in Texas (Harper et al., 1990). On the other hand, age has been found to be either negatively related with adoption, or not significant in farmers' adoption decisions. In studies on adoption of land conservation practices in Niger (BaiduForson, 1999), rice in Guinea (Adesiina and Baidu-Forson, 1995), fertilizer in Malawi (Green and Ng'ong'ola, 1993), age was either not significant or was negatively related to adoption.

A number of literature that pursued to establish the effect of education on adoption in most cases relate it to years of schooling. Generally, education is thought to create a promising rational attitude for the acceptance of new practices, especially information-intensive and management-intensive practices (Waller et al, 1998; and Caswell et al., 2001). Rogers (1995) and Ehler and Bottrell (2000) stated that technology difficulty has a negative effect on adoption and this could only be deal with complete education. Furthermore, access to credit is expected to increase the probability of adoption. For instance, it has been reported that most small scale farmers in the country are unable to afford basic marketing technologies such as smart phone with $4 G$ connection and internet resulting in low profit margin due to poverty and limited access to credit (Ministry of Agriculture, 2014).

From the previous discussion, it is concluded that though a number of researches have been conducted across the world on technology adoption, there is a lack of literature on the specific factors that influence modern agricultural marketing technologies, especially among small and medium farmers in Bangladesh. This is a severe gap that must be tied together if the problem of low technology adoption is to be addressed and improved the agricultural marketing system.

\section{METHODOLOGY OF THE STUDY}

\section{The survey}

Northern Bangladesh is selected for this study. Because of this region has produces surplus agricultural commodities. Marketing of these commodities is a vital issue for this region. Northern Bangladesh is the northwestern part of the country. It consists of 16 districts of Rajshahi and Rangpur division. Two districts namely Naogaon and Dinajpur have been selected purposively from two divisions as they possess same sub-tropical climate and agricultural activities. After that one upazilla from each district has been selected i.e., Mohadevpur from Naogaon, out of 11 upazillas and Hakimpur from Dinajpur, out of 13 upazillas following Simple Random Sampling (SRS) lottery method. Again as each upazilla has some unions; therefore, one union from each upazilla has been selected in the same manner. Finally, four villages were selected in the same technique i.e., two villages from each union (Baghdob from Chandas union of Mohadevpur Upazilla and Ghonashampur from Khatta Madhabpara union of Hakimpur Upazilla).

The population of the study is the number of households engaged in production and marketing of agricultural 
commodities and living permanently in the selected village. Total number of households in selected two upazillas is 98984 (Population and Housing Senses, BBS, 2011). Total number of households engaged in agricultural commodities production and marketing in selected two upazillas is 80177 (Upazila Agriculture Office).Therefore, $81 \%$ of total households are engaged in agricultural commodities production and marketing in the study area. Total number of households in selected two villages is $(575+204)=779$ and $(466+165)=$ 631households are engaged in agricultural commodities production and marketing (Population and Housing Senses, BBS, 2011).Therefore, size of the study population $(\mathrm{N})$ is 631. By using the following formula we can determine the sample size (Kotheri, 2014, p. 179).

$n=\frac{z^{2} \cdot N \cdot p \cdot q}{e^{2}(N-1)+z^{2} \cdot p \cdot q}$

$=\frac{(1.96)^{2} \times 631 \times 0.81 \times 0.19}{(0.05)^{2}(631-1)+(1.96)^{2} \times 0.81 \times 0.19}=172.23$

$=173$

Here,

$n=$ Sample size

$N=$ Total number of households (engage in agricultural commodities production and marketing)

$z=$ Confidence level (at 95\% probability $=1.96$ )

$e=$ Acceptable error (error limit 5\%, i.e., 0.05)

$p=$ Estimated population proportion $=0.81$

(Kotheri, C.R., 2014, p. 179).

$$
q=(1-p)=(1-0.81)=0.19
$$

So that, sample size is 173 , but researcher collected data from 216 respondents. The pieces of information gathered from the interviews were the basic inputs for analysis. SPSS (Version 22) was the software for the data analysis.

\section{The analytical Framework}

Using the logit model, the factors that influence farm households' decisions to adopt modern agricultural marketing technologies were estimated. The use of the logit model for this analysis is consistent with the literature on adoption (Griliches, 1957; Lionberger, 1960; Rogers, 1995; Alston et al., 1995) which describes the process of adoption as compelling on a logistic nature. The study used the beginning decision-making theory proposed by Hill and Kau (1973), and Pindyck and Rubinfeld (1998). The theory points out the fact that when farmers are faced with a decision to adopt or not to adopt a technology, there is a reaction beginning which is dependent on a certain set of factors. As such, at a certain value of stimulus below the beginning, no adoption is observed while at the critical beginning value, a reaction is stimulated. Such phenomena are generally modeled using the relationship:
$Y=\beta X_{i}+u_{i}$

Where $Y_{i}$ is equal to one (1) when a choice is made to adopt and zero $(0)$ otherwise; this means:

$Y_{i}=1$ if $X_{i}$ is greater than or equal to a critical value, $X^{*}$ and $Y_{i}=0 X_{i}$ is less than a critical value, $X^{*}$.

Note that $X^{*}$ represents the combined effects of the independent variables $\left(X_{i}\right)$ at the beginning level. Equation 1 represents a binary logistic model involving the estimation of the probability of adoption of a given technology $(Y)$ as a function of independent variables $(X)$. Mathematically this is represented as:

$\operatorname{Prob}\left(Y_{i}=1\right)=F\left(\beta^{\prime} X_{i}\right)$

$\operatorname{Prob}\left(Y_{i}=0\right)=1-F\left(\beta^{\prime} X_{i}\right)$

Where $Y_{i}$ is the observed response for $i^{\text {th }}$ observation of the response variable, $Y$. This means that $Y_{i}=1$ for an adopter (i.e. farmers who adopt modern agricultural marketing technologies) and $Y_{i}=0$ for a non-adopter (i.e. farmers who do not adopt modern agricultural marketing technologies). $X_{i}$ is a set of independent variables such as farm size along with others, associated with $\mathrm{i}^{\text {th }}$ individual, which determine the probability of adoption, (P). The function, F may take the form of a normal, logistic or probability function. The logistic model uses a logistic cumulative distributive function to estimate, $\mathrm{P}$.

$P(Y=1)=\frac{e^{\beta \prime X}}{1+e^{\beta \prime X}}$

$P(Y=0)=1-\frac{e^{\beta \prime X}}{1+e^{\beta \prime X}}$

According to Greene (2008), the probability model is a regression of the conditional expectation of $\mathrm{Y}$ on $\mathrm{X}$ giving:

$E(Y / X)=1\left[F\left(\beta^{\prime} X\right)\right]+0\left[1-F\left(\beta^{\prime} X\right)\right]=F\left(\beta^{\prime} X\right)$

Since the model is non-linear, the parameters are not necessarily the marginal effects of the various independent variables. The relative effect of each of the independent variables on the probability of adoption is obtained by differentiating equation (6) with respect to $\mathrm{X}_{\mathrm{ij}}$ resulting in equation (7):

$\frac{\partial P_{i}}{\partial X_{i j}}=\left[\frac{e^{\beta^{\prime} X}}{\left(1+e^{\beta^{\prime} X}\right)^{2}}\right] \beta=F\left(\beta^{\prime} X\right)\left[1-F\left(\beta^{\prime} X\right)\right] \beta$

Maximum likelihood method was used to estimate the parameters.

The judgment for applying the logit model in this paper is that, the dependent variable is categorical and the farmer would decide to adopt modern agricultural marketing technologies at a given time when the combined effects of certain factors exceed the natural resistance to change his decision. The preference for the logit model to the conventional linear regression models, in analyzing the factors influencing the 
decisions of farmer to adopt modern agricultural marketing technologies is based on the fact that, the parameter estimates from the earlier are asymptotically consistent and efficient. The estimation technique employed also resolves the problem of heteroscedasticity and constrains the conditional probability of making the decision to adopt technology to lie between zero (0) and one (1).

The empirical model for the logit model estimation is specified as,

$Y_{i}=\log \frac{P_{i}}{1-P_{i}}=\alpha+\beta X_{i}+u_{i}$

Where $X_{i}$ is the combined effects of independent variables $X$ that encourage or discourage farmer's decision to adopt modern agricultural marketing technologies.

$\log \frac{P_{i}}{1-P_{i}}$ is the log-odds in favour of farmers decision to adopt modern agricultural marketing technologies.

$X_{1}, X_{2}, X_{3} \ldots \ldots \ldots . . . . X_{i}$ are the factors that encourage or discourage farmers to adopt modern agricultural marketing technologies and these are defined as follows;

$\mathrm{X}_{1}=$ Age of the Farmer

$\mathrm{X}_{2}=$ Formal education of the farmer measured as year of schooling

$\mathrm{X}_{3}=$ Farm size in Bigha

$\mathrm{X}_{4}=$ Cost of technology, dummy $(1=$ Affordable; $0=$ Otherwise)

$\mathrm{X}_{5}=$ Level of expected benefits, dummy $(1=$ High expected benefits; $0=$ Otherwise

$\mathrm{X}_{6}=$ Off-farm income generating activities, dummy $(1=$ Yes; 0 = Otherwise)

$\mathrm{X}_{7}=$ Profitability of using technology, dummy (1 = Yes; 0 $=$ Otherwise)

$\mathrm{X}_{8}=$ Access to institutional credit, dummy ( 1 = Has easy access to institutional credit; $0=$ Otherwise)

$\mathrm{X}_{9}=$ Farmers training about use of marketing technologies, dummy ( 1 = Yes: $0=$ Otherwise $)$

\section{RESULTS AND DISCUSSION}

\section{Socio-Demographic Characteristics of Respondent}

We have taken different types of farmers in Northern Bangladesh, more specifically Bagdob village of Mohadevpur Upazilla in Naogaon District and Ghanashampur village of Hakimpur Upazilla in Dinajpur District as far as age is concerned. The age limit of the farmers is from 22 years to 80 years. The survey result shows that most of the farmers are young and energetic. 48.6 per cent farmers are in the age limit between 25 years to 45 years. Result revealed that majority $(82.87 \%)$ of farmers are between 30 years to 60 years age and are assumed to be driving the households decision making process about adoption of modern agricultural marketing technology. The implication of this findings is that most of the farmer in our study area belong to the economically active age group and their technology adoption behaviors are critical for the improvement of marketing profit. The highest number of farmer's age lie between the age group of 45 years to 50 years. On the other hand, a major portion (37\%) of farmers has the experience of primary education in the length of five years schooling. 25 percent of them have never attended the school. 22.2 percent of them continue their education at SSC level, the farmer include here who don't pass the secondary school certificate examination but they complete ten years of schooling length. On the other hand 15.7 percent have HSC to graduation level of formal education. Only eleven farmers out of two hundred and sixteen farmers have higher degree. This means that the findings are representative of both literate and illiterate residents of Northern Bangladesh. We have shown these results in Table 1.

Table 1: Socio-Demographic Characteristics of Respondent

\begin{tabular}{|c|c|c|}
\hline Age & No. of Farmer & Percent \\
\hline $20-30$ & 22 & 10.2 \\
\hline $30-40$ & 57 & 26.4 \\
\hline $40-50$ & 73 & 33.8 \\
\hline $50-60$ & 49 & 22.7 \\
\hline $60-70$ & 13 & 6.0 \\
\hline $70-80$ & 2 & .9 \\
\hline Total & 216 & 100.0 \\
\hline \multicolumn{2}{|c|}{ Education } \\
\hline Never attend school & 54 & 25.0 \\
\hline Primary & 80 & 37.0 \\
\hline SSC & 48 & 22.2 \\
\hline HSC & 23 & 10.6 \\
\hline Higher Education & 11 & 5.1 \\
\hline Total & 216 & 100.0 \\
\hline \multicolumn{2}{|c|}{ Farm Size } \\
\hline Small Farm & 157 & 72.7 \\
\hline Medium Farm & 43 & 19.9 \\
\hline Large Farm & 16 & 7.4 \\
\hline Total & 216 & 100.0 \\
\hline
\end{tabular}

Factors Influencing Farm Households Modern Agricultural Marketing Technology Adoption

The results of binary logistic regression analysis of the data showed that the full logistic regression model containing all the predictors was statistically significant, Chi-square $=224.809, \mathrm{df}=9, \mathrm{~N}=216, \mathrm{p}<$ 0.001 (Table 2.1)indicating that the explanatory variables significantly predicted the outcome variable, Adoption of modern agricultural marketing technology. The results of the data analysis presented 
in Table 2 show the logistic regression coefficients. Wald test and odds ratios for each of the predictor variables. The results of Cox \& Snell and Nagelkerke $R$ square estimates indicated that the whole model explained between $64.7 \%$ and $87.9 \%$ of the variance that can be predicted from the independent variables (Table 2.1). The Hosmer and Lemeshow tests indicate that the $\mathrm{p}$-value is 0.747 , which is above 0.05 (Table 2.1). So that, the estimated model has adequately fit the data. The model classified correctly $94 \%$ of the respondent who were adopt modern agricultural marketing technologies and $94 \%$ of the respondent who were not to adopt modern agricultural marketing technologies, for an overall classification success rate of $94 \%$.
Table 2.1: Analysis for Binary Logistic Regression Model

\begin{tabular}{|c|c|c|c|c|}
\hline \multicolumn{5}{|c|}{ Omnibus Tests of Model Coefficient } \\
\hline & & Chi-square & df & sig. \\
\hline Step 1 & Step & 224.809 & 9 & .000 \\
\hline & Block & 224.809 & 9 & .000 \\
\hline & Model & 224.809 & 9 & .000 \\
\hline \multicolumn{5}{|c|}{ Model Summary } \\
\hline Step & $\begin{array}{c}\text {-2 Log } \\
\text { likelihood }\end{array}$ & $\begin{array}{c}\text { Cox \& Snell } \\
\text { R Square }\end{array}$ & $\begin{array}{c}\text { Nagelkerke } \\
\text { R Square }\end{array}$ & \\
\hline 1 & 62.951 & .647 & .879 & \\
\hline \multicolumn{5}{|c|}{ Hosmer and Lemeshow Test } \\
\hline Step & Chi-square & df & sig. & \\
\hline 1 & 5.097 & 8 & .747 & \\
\hline
\end{tabular}

Table 2.2: Factors Influencing Adoption of Marketing Technology

\begin{tabular}{|c|c|c|c|c|c|c|c|c|}
\hline \multirow[b]{2}{*}{ Variable } & \multirow[b]{2}{*}{ B } & \multirow[b]{2}{*}{ S.E } & \multirow[b]{2}{*}{ Wald } & \multirow[b]{2}{*}{ df } & \multirow[b]{2}{*}{ Sig. } & \multirow[b]{2}{*}{$\operatorname{Exp}(B)$} & \multicolumn{2}{|c|}{ 95\% CI for EXP(B) } \\
\hline & & & & & & & lower & upper \\
\hline Age of the respondent & -.077 & .034 & 5.021 & 1 & .025 & .926 & .865 & .990 \\
\hline Formal education of the respondent & -.688 & .363 & 3.593 & 1 & .058 & .502 & .247 & 1.024 \\
\hline Farm size in Bigha & .451 & .109 & 17.040 & 1 & .000 & 1.570 & 1.267 & 1.944 \\
\hline Cost of technology & -.449 & .797 & .318 & 1 & .573 & .638 & .134 & 3.040 \\
\hline Level of expected benefits & 3.125 & .803 & 15.165 & 1 & .000 & 22.766 & 4.722 & 109.755 \\
\hline Off-farm income generating activities & 1.719 & .753 & 5.205 & 1 & .023 & 5.577 & 1.274 & 24.413 \\
\hline Profitability of using technology & .157 & 1.225 & .016 & 1 & .898 & 1.170 & .106 & 12.909 \\
\hline Access to institutional credit & 3.793 & .820 & 21.394 & 1 & .000 & 44.410 & 8.900 & 221.610 \\
\hline $\begin{array}{l}\text { Farmers training about use of marketing } \\
\text { technology }\end{array}$ & 2.328 & 1.123 & 4.296 & 1 & .038 & 10.257 & 1.135 & 92.690 \\
\hline Constant & -3.101 & 2.072 & 2.240 & 1 & .134 & .045 & & \\
\hline
\end{tabular}

The age of the farmer was found to have a negative relationship with probability of adoption was found to be significant at the 5 percent level (Table 2.2). This means farmers of older ages are less likely to adopt modern agricultural marketing technologies and the vice versa.

Formal education within the farmer was found to have a negative relationship with probability of adoption and significant at 10 percent level (Table 2.2). The result implies that farmers with less education are more likely to adopt modern agricultural marketing technologies than those with well education.

Farm size was found to have a positive relationship with the probability of adoption and significant at 1 percent level (Table 2.2). This result implies that large scale farmers are more motivated to adopt new technologies than small scale farmers. These results present a serious challenge for policy makers and implementers to encourage adoption of modern agricultural marketing technologies in the study areas. Because majority of the farmers $(72.7 \%)$ in our study areas are small and marginal farmers (Table 1$)$.

The cost of modern agricultural marketing technologies was found to be negatively related to the probability of adoption (Table 2.2) and it was found to be insignificant.
These results reveal that if the technology is expensive/costly for the farmer, there is a low probability that the farmer will adopt the technology. Apart from this, the household expenditure also influences technological adoption. If household expenditure and cost of technology both are high, the probability of technological adoption become low. Because most of the technologies are not affordable for small or marginal farmers. Effort to encourage the adoption of modern technologies in the marketing of agricultural commodities, the price of the technologies must be brought at the portable level, especially for the poor farmers.

The level of expected benefit from adopting a given technology was found to be positively associated to the probability of adoption and it was found to be significant at the 1 percent level (Table 2.2). The results implies that level of expected benefits from adopting a modern agricultural marketing technology to be higher than farmers traditional method of agricultural commodities marketing, they agree to adopt the technology and otherwise not.

Off-farm income generating activities of farmers was found to be positively associated to the probability of adoption and it was found to be significant at the 5 percent 
level (Table 2.2). This implies that the positive change of off-farm income generating activities of farmers create a positive change to their probability of adoption modern agricultural marketing technologies.

Profitability of using technology was found to be positively related to the probability of adoption and it was found to be insignificant (Table 2.2). This implies that if farmers profitability of using technology to be higher, then they are most likely to adopt modern agricultural marketing technology and the vice versa.

Access to institutional credit was found to have a positive relationship with the probability of adoption and it was found to be significant at 1 percent level (Table 2.2). This means that farmers are most likely to adopt modern agricultural marketing technologies if they have easy access to institutional credit. The result shows that institutional credit is a vital helping factor for adoption of modern agricultural marketing technologies. This is particularly so given that most modern technologies are expensive which makes it difficult for many farmers, especially those in rural areas where poverty is endemic to be able to acquire and utilize them without assistance in the form of supply of affordable credit and other financial services (Benin et al., 2009).

Farmers' training about use of marketing technologies was found to have a positive association with the probability of adoption and it was found to be significant at 5 percent level (Table 2.2). It means that farmers are most likely to adopt modern agricultural marketing technologies if they have a training about use of marketing technologies. Therefore, training about use of technology is an important factor for the illiterate or less literate farmers for adopting modern agricultural marketing technologies.

\section{CONCLUSION}

We have taken nine explanatory variables in our model which influences the farmers' decision to adopt modern agricultural marketing technologies. We have found three explanatory variables i.e. age of the farmer, formal education of the farmer and cost of technologies negatively influences the farmers' decision to adopt modern agricultural marketing technologies in Northern Bangladesh. The remaining six explanatory variables i.e. farm size, level of expected benefits, off-farm income generating activities, profitability of using technology, access to institutional credit and training about use of marketing technologies positively influences the farmers' decision to adopt modern agricultural marketing technologies in Northern Bangladesh. Seven independent variable i.e. age of the farmer, formal education of the farmer, farm size, and level of expected benefits, off-farm income generating activities, access to institutional credit and training about use of marketing technologies are statistically significant factors that influence the decision of farmers to adopt modern agricultural marketing technologies in Northern Bangladesh. Only two independent variable i.e. cost of technologies and profitability of using technology are statistically insignificant factors that influence the decision of farmer to adopt modern agricultural marketing technologies in Northern Bangladesh. So it is concluded that the farmers' decision to adopt modern agricultural marketing technologies depends on their socio-economic status and organizational effectiveness. We recommend that such policies should be made so that the positive impact factors on technologies adoption are properly utilized and negative issues are reduced.

\section{REFERENCES}

Abara, I. O. C. \& Singh, S. (1993). Ethics and biases in technology adoption: The small farm argument. Technological Forecasting and Social Change, 43, 289-300.

Adesiina, A.A. \& Baidu-Forson, J. (1995). Farmers' perceptions and adoption of new agricultural technology: Evidence from analysis in Burkina Faso and Guinea, West Africa. Journal of Agricultural Economics, 13, 1-9.

Alston, J.M., Norton, G.W. and Pardey, P.G. (1995). Science Under Scarcity: principles and Practice for Agricultural Research Evaluation and Priority Setting. Cornell University Press, Ithaca (reprinted in soft cover by CAB International 1998).

Baidu-Forson, J. (1999). Factors influencing adoption of landenhancing technology in the Sahel: Lessons from a case study in Niger. Journal of Agricultural Economics, 20, 231-239.

Bangladesh Bureau of Statistics, Ministry of Planning, Bangladesh (2011).Community Report, Population and Housing Census, http//:www.bbs.gov.bd.(accessed in March 19, 2017).

Benin, S., Mogues, T., Cudjoe, G., \& Randriamamonjy, J. (2009). Public expenditures and agricultural productivity growth in Ghana. Contributed Paper for International Association of Agricultural Economists in Beijing 2009.

Boahene, K., Snijders, T.A.B. \& Folmer, H. (1999). An integrated socio-economic analysis of innovation adoption: The case of Hybrid Cocoa in Ghana. Journal of Policy Modeling, 21(2), 167-184.

Caswell, M., Fuglie, K., Ingram, C., Jans S. \& Kascak C. (2001). Adoption of Agricultural production practices: Lessons learned from the US. Department of Agriculture Area Studies Project. US Department of Agriculture, Resource Economics Division, Economic Research Service, Agriculture Economic Report No. 792. Washington DC.

Daku, L. (2002). Assessing farm-level and aggregate economic impacts of olive integrated pest management programs in Albania. PhD. Dissertation, Virginia Polytechnic Institute and State University, David, Lynne Riener Publishers.

Doss, C. R \& Morris, M. L. (2001). How does gender affect the adoption of agricultural innovation? The case of improved maize technologies in Ghana. Journal of Agricultural Economics, 25, 27-39.

Ehler, L.E \& Bottrell D.G. (2000). The illusion of integrated pest management. Issues in science and technology. Bell and Howell Information and Learning Company, pp. 61-64. 
Feder, G. \& Slade R. (1984). The acquisition of information and the adoption of new technology. American Journal of Agricultural Economics, 66, 312-320.

Feder, G., Just E. R. \& Zilberman D. (1985). “Adoption of agricultural innovations in developing countries: A survey. Economic Development and Cultural Change, 33, 255-298.

Fernandez-Cornejo, J. (1996). The microeconomic impact of IPM adoption: Theory and application. Agricultural and Resource Economic Review, 25, 149-160.

Fernandez-Cornejo, J. (1998). Environmental and economic consequences of technology adoption: IPM in viticulture. Agricultural Economics, 18, 145-155.

Green, D.A.G., \& Ng'ong'ola D.H. (1993). Factors affecting fertilizer adoption in less developed countries: An application of multivariate logistic analysis in Malawi. Journal of Agricultural Economics, 44 (1), 99-109.

Griliches, Z. (1957), Specification Bias in Estimates of Production Functions, American Journal of Agricultural Economics, 39, (1), $8-20$

Harper, J. K., Rister, M. E., Mjelde, J. W., Drees, B. M. \& Way, M O. (1990). Factors influencing the adoption of insect management technology. American Journal of Agricultural Economics, 72(4), 997-1005.

Hill, L. and Kau, P. (1973). "Application of Multivariate Probit to a Threshold Model of Grain Dryer Purchasing Decisions," American Journal of Agricultural Economics, Agricultural and Applied Economics Association, vol. 55(1), pages 19-27.

Kasenge, V. (1998). Socio-economic factors influencing the level of soil management practices on fragile land. In proceedings of the 16th Conference of Soil Science Society of East Africa (Eds.: Shayo-Ngowi, A.J., G. Ley and F.B.R Rwehumbiza), 13th-19th, Tanga, Tanzania. pp. 102-112.

Kotheri, C.R. (2014). Research Methodology: Methods and techniques, 2nd ed. New Delhi: New Age International limited, pp. 179.
Lionberger, H.F. (1960), Adoption of New Ideas and Practices, Ames (Iowa): Iowa State University Press.

McNamara, K. T., Wetzstein M. E., \& Douce G.K. (1991). Factors affecting peanut producer adoption of integrated pest management. Review of Agricultural Economics, 13, 129-139.

Ministry of Agriculture, Bangladesh (2009). Bangladesh Agricultural Policy, http://dae.portal.gov.bd/sites/default/files/files/dae.por tal.gov.bd/page/dd7d2be1_aeef_452f_97748c23462ab73a/ NAP.pdf (accessed March 27, 2017)

Mugisa-Mutetikka, M., Opio., A.F. Ugen., M.A. Tukamuhabwa, P., Kayiwa, B.S., Niringiye, C. and Kikoba, E. (2000) "Logistic Regression Analysis of Adoption of New Bean Varieties in Uganda." Unpublished.

Nkonya, E., T. Schroeder, and Norman D. (1997). Factors affecting adoption of improved maize seed and fertilizer in northern Tanzania. Journal of Agricultural Economics, 48(1), 1-12.

Pindyck, R.S. and Rubinfeld, D.L. (1998) Econometric Models and Economic Forecasts. 4th Edition, Irwin-McGraw- Hill, Boston.

Rogers, E.M. (1995). Diffusion of innovations 3rd Edition. New York: The Free Press.

Statistical Year Book 2015, Bangladesh Bureau of Statistics, Ministry of Planning, Bangladesh, http:/ /203.112.218.65/WebTestApplication/userfiles/Ima ge/SubjectMatterDataIndex/YearBook15.pdf (accessed March 27, 2017).

Waller, B.E., Hoy, C.W., Henderson, J.L, Stinner B., \& Welty C. (1998). Matching innovations with potential users: A case study of potato IPM practices. Agriculture, Ecosystems and Environment, 70, 203- 215.

Yaron, D., Dinar A., \& Voet H. (1992). Innovations on family farms: The Nazareth Region in Israel. American Journal of Agricultural Economics, 361-370.

$--0--$ 
Online Archive: https://abc.us.org/ojs/index.php/abr/issue/archive 